Abstracta Iranica Abstracta Iranica

Revue bibliographique pour le domaine irano-aryen

Volume 27 | 2006

Comptes rendus des publications de 2004

\title{
The Naqshbandi Sufi Tradition - Guidebook of Daily Practices and Devotions. Islamic Supreme Council of America, 2004, 341 p.
}

\section{Pierre Lory}

\section{(2) OpenEdition}

Journals

Édition électronique

URL : http://journals.openedition.org/abstractairanica/6258

DOI : 10.4000/abstractairanica.6258

ISSN : 1961-960X

Éditeur :

CNRS (UMR 7528 Mondes iraniens et indiens), Éditions de l'IFRI

\section{Édition imprimée}

Date de publication : 15 mai 2006

ISSN : 0240-8910

Référence électronique

Pierre Lory, «The Naqshbandi Sufi Tradition - Guidebook of Daily Practices and Devotions. Islamic Supreme Council of America, 2004, 341 p. », Abstracta Iranica [En ligne], Volume 27 | 2006, document 273, mis en ligne le 02 janvier 2007, consulté le 25 septembre 2020. URL : http://

journals.openedition.org/abstractairanica/6258; DOI : https://doi.org/10.4000/abstractairanica.6258

Ce document a été généré automatiquement le 25 septembre 2020

Tous droits réservés 


\section{The Naqshbandi Sufi Tradition - Guidebook of Daily Practices and Devotions. Islamic Supreme Council of America, 2004, 341 p.}

\section{Pierre Lory}

L’A. est le principal disciple du Maître naqshbandi Naẓīm Ḥaqqānī, et son représentant aux Etats-Unis, où il déploie une grande activité dans la défense et la propagation de cette confrérie. Le présent livre, suite d'une série déjà longue de publications, est l'expression de cette activité. Il ne s'agit pas d'un ouvrage de type académique, mais d'une présentation de la spiritualité soufie (pp.18-80), de sa congruence avec l'orthodoxie (pp. 81-96), du rôle du dikr (pp. 97-158). La seconde partie donne le texte arabe et la traduction anglaise des textes liturgiques de la tradition naqshbandie dans les diverses occasions. L'ensemble relève de la littérature spirituelle, écrite par un Maitre pour des croyants. C'est à titre de témoignage de foi soufie s'adressant à des musulmans vivant au cœur de la civilisation moderne qu'il peut intéresser, non pour sa pertinence scientifique.

\section{INDEX}

Thèmes : 8 . Soufisme 
AUTEURS

PIERRE LORY

EPHE - Paris 